\title{
Study on the Relationship between Population Urbanization and Economic Growth, Industrial Structure:Taking Bijie City as an Example
}

\author{
HONG,Yeying ${ }^{1,2}$ \\ ${ }^{1}$ School of Ethnology and Sociology \\ Gui zhou Minzu University \\ Guiyang City in Guizhou, China \\ ${ }^{2}$ The Communist Party of China Chongqing \\ Fuling District Party Committee Party School \\ Fuling District in Chongqing, China \\ hyeying123@163.com
}

\begin{abstract}
The aim of this study was that how to promote the development of population urbanization in the poor mountainous area, and to realize the industrial structure adjustment and upgrading, and to coordinate the population urbanization and economic growth, industrial transformation, promote each other. This paper On the Basis of the existing theory achievement and consideration on the basis of regional natural environment, and with the aid of the non-stationary time series econometrics analysis, selects the Grange causality test of variables, to explore the population urbanization and economic growth, structural change of causality. The results show that: (1) Economic growth and structure change of one-way causal relationship between population urbanization; (2) The economic growth is the driver of the urbanization level, the urbanization level is not the cause of the economic growth;(3)The Grange causality between urbanization and three industry employment relationship is not significant; (4) The adjustment of industrial structure upgrade is to promote the process of urbanization, the urbanization level is not due to the industrial structure; (5)The population urbanization for economic growth and structure change of the feedback effect is not obvious; Population urbanization lags behind the economic development. The original in this paper is that:(1) Qualitative and quantitative analysis, investigation research and literature research methods such as the integrated use of, the implementation method of innovation;(2) Breakthrough most only industrial structure effect on urbanization of individual study, from the Angle of the two-way interaction between industrial structure and urbanization on the empirical analysis of innovation of research perspective.
\end{abstract}

Keywords-Population Urbanization; Economic growth; Industrial structure; Empirical Analysis; Bijie City

\section{INTRODUCTION}

With the world to speed up the process of Industrialization, as well as Industrialization and Industrial structure changes to the town to change stimulative effect, also show the Urbanization on regional Economic growth and Industrial structure evolution to produce consumption, spatial aggregation, space support effective response[1]. The relationship between Urbanization and Industrial structure from many domestic and foreign scholars[2][3].The domestic scholars from different angles on the evolution of Industrial structure and the Urbanization, the problem such as the relation[4][5].The above research, the Industry structure and Urbanization research is relatively single, and focuses on the relationship between Urbanization and Industrial structure, and lack of Urbanization and Economic growth, structural changes in the relationship between quantitative analysis.

Bijie City is located in the northwest of Guizhou Province, and the province of the typical karst mountain area. The regional geographical location, and land is barren, impoverished Population is much, the economic structure of the complex. With western the propulsion of big development, Bijie city Urbanization level has been improved, but compared with other regions in Guizhou Province, there is a big gap. For a gradual development in the region, Industrialization and Urbanization, it is my region Economy development strategy, and Urbanization is too lag Industrialization will become the bottleneck of the development of Economic society. Study in the Bijie City population urbanization development present situation, discusses the urbanization and economic growth, structural change between running relationship. Research on China poverty stricken karst mountainous area especially the southwest and impoverished a mountainous area how to promote urbanization development to realize the adjustment and upgrade of Industrial structure, and better coordination of urbanization and economic growth, industrial transformation and promote each other, become the karst region Industry transition problem must consider the problem. At this stage is the Bijie City realizes the sustainable development request inevitably, but also for the similar background region to provide a certain reference value.

\section{RESEARCH METHODS AND DATA DESCRIPTION}

\section{A. Research methods}

The Population Urbanization and Economic growth, Industrial structure to study the relationship between many result. The basic logic is that: To speed up the process of 
Industrialization caused the changes of Industrial structure, led to the diversification of Industrial structure and height change, cause of rural population to urban migration, leading to Population Urbanization. On the Bases of the references[6][7][8][9][10].Directly forward area city, and the city of Chinese regional development and regional city to do an in-depth study of the process.

The study confirmed although the level of Population Urbanization and Economic development level between high positive correlation, but did not distinguish between Economic growth and structural change on Population Urbanization in the short-term effect and long-term effect, no consideration of Population Urbanization on the Economic growth, structural change may produce the feedback effect. On the Urbanization and Economy, the relationship between Industrial structure also made active exploration, but more is the qualitative analysis and the establishment of regression model for quantitative research, and most of them focus on the macro level. In this paper, based on the existing theory achievement, Sufficient attention in Bijie City karst topography, with the aid of the econometrics of non-stationary time series analysis. Selected the Bijie city Urbanization rate, GDP per capita and the output value of the two or three industry and the first industry and several main variables. These variables on the time sequence of the logarithm, and then choose Granger inspection, in order to explore the Urbanization and the Economic growth, Industrial structure changes of causality and optimize Industrial structure dynamic interaction[11].

\section{B. Variable selection}

From 1988 to 2014 in Bijie City of the relevant data for the study of time; selecting variables: Urbanization rate, GDP per capita and the output value of the two or three industry and the first industry.

1) The level of Urbanization. This article select the town Population holds total Population proportion, denoted $L n U R_{t}$.

2) Economic growth. In order to eliminate the influence of prices reflect the actual economic development situation, choice are calculated at comparable prices. This paper select Per capita GDP Index ( $1978=100)$ this index to measure the level of Economic development, denoted $\operatorname{LnGDP}{ }_{t}$.

3) Industrial structure. This article selects second, the output value of the three industry and the first industry production value proportion reflect changes in the Industrial structure, denoted

$$
\operatorname{Ln} \frac{G S_{t}+G T_{t}}{G F_{t}}
$$

4) Data source: "Bijie brilliant sixty years (19492009)" and “Guizhou statistical yearbook (1989-2015)", Statistical communique, related data.

\section{POPULATION URBANIZATION AND ECONOMIC GROWTH}

\section{A. Model construction}

If the city to speed up the process by rapid Economic growth causes, can thus be selected per capita gross domestic product ( GDP ) as explanatory variables, for the elimination of price factors influence on GDP in 1980, with comparable prices per capita GDP. In addition, taking into account the Urbanization process and the dynamic characteristic of the Population, the rate of Urbanization lagUR $\mathrm{t}_{\mathrm{t}-1}$ phase. As another explanatory variables, using the related data from 1988 to 2014, using least square method (OLS) is obtained by fitting:

$$
\begin{aligned}
& U R_{t}=0.0036 \operatorname{LnGDP} P_{t}+0.7809 \operatorname{LnUR}_{t-1} \\
& (1.6233) \quad\left(4.7442^{* * *}\right) \\
& \overline{R^{2}}=0.8097, \mathrm{SE}=0.0110, \mathrm{DW}=1.5522
\end{aligned}
$$

Type, for the freedom to adjust the coefficient of determination, SE as the standard error of regression, DW Dubin Watson Test value, the estimated coefficients below the number of brackets for the $t$ test value, police said on $1 \%$ levels of statistical significance.

The estimated results showed that, the current Economic growth of Population Urbanization rate influence is positive, but the results is not significant, the rate of Population Urbanization process largely only by the rate of Urbanization lag variable to explain. Rate of Urbanization lag of Urbanization rate of marginal contribution is 0.7809, the Bijie city town to change rate, largely by last year's Urbanization rate of contribution. The type of order autocorrelation, model (1) to the. After fitting, as follows: the model( 2).

$$
\begin{gathered}
\operatorname{LnUR}_{t}=0.011 \operatorname{LnGDP}+0.944 \operatorname{LnUR}_{t-1} \\
\frac{(1.536)}{R^{2}}=0.741, \mathrm{SE}=0.0141, \mathrm{DW}=1.942
\end{gathered}
$$

(2)Type basic elimination of the first order autocorrelation, and the adjusted goodness-of-fit is higher. The type of conclusion and the former type is basically the same, not in here.

\section{B. Granger causality test}

In this paper we select Spss11.5 to statistical analysis. The results is that: Population Urbanization and Economic growth between the Granger causality( The rest results as shown in TABLE 1, TABLE 1 shows that: From the Bijie city Economic growth of Population Urbanization between the one-way causal relationship, namely Economic growth is to promote Population Urbanization level, Population Urbanization level higher than the causes of Economic growth. 
PRESS

TABLE I. THE POPUlation URBANIZATION AND ECONOMIC GROWTH BETWEEN THE GRANGER CAUSALITY TEST

\begin{tabular}{|c|c|c|c|c|}
\hline The null hypothesis & $\begin{array}{c}\text { The } \\
\text { lagging } \\
\text { number }\end{array}$ & $\begin{array}{c}\text { The } \\
\text { value of } \\
\text { F }\end{array}$ & $\begin{array}{c}\text { The } \\
\text { value of } \\
\text { P }\end{array}$ & Conclusion \\
\hline $\begin{array}{l}\text { The per capita GDP } \\
\text { (LnGDP) does not } \\
\text { cause the population } \\
\text { urbanization rate (UR) }\end{array}$ & 2 & 5.374 & $0.019^{* *}$ & Refuse \\
\hline $\begin{array}{l}\text { The population } \\
\text { urbanization rate } \\
\text { ( UR ) does not induce } \\
\text { GDP of average per } \\
\text { capita (LnGDP) }\end{array}$ & 2 & 0.301 & 0.745 & Accept \\
\hline $\begin{array}{l}\text { The per capita GDP } \\
\text { ( LnGDP ) does not } \\
\text { cause the population } \\
\text { urbanization rate } \\
\text { ( LnUR) }\end{array}$ & 2 & 3.844 & $0.0467^{* *}$ & Refuse \\
\hline $\begin{array}{l}\text { The population } \\
\text { urbanization rate } \\
\text { ( LnUR ) does not } \\
\text { induce GDP of average } \\
\text { per capita (LnGDP) }\end{array}$ & 2 & 0.457 & 0.6423 & Accept \\
\hline
\end{tabular}

According to the above inspection, irrespective of the function form of the model, the Population Urbanization and Economic growth have a one-way causal relationship. That is from the beginning of 1988, the Bijie City of Population Urbanization and Economic growth of the relationship between one-way relationship, Economic growth is the reason for the improvement of Urbanization, and illustrates the addition of Economic growth, the other factors on Population Urbanization effect may be greater[12].

\section{POPULATION URBANIZATION AND INDUSTRIAL STRUCTURE}

\section{A. Model construction}

Population Urbanization, is not only from the first industry to the second, the tertiary industry transfer and the agglomeration process, is also the industry structure to second, the tertiary industry gradually tilting process. Therefore, selection of the tertiary industry output value second, and the first industrial output value ratio as independent variables, to explain the Population Urbanization rate changes. Get the following model:

$$
\begin{aligned}
& \operatorname{LnGDP} P_{t}=0.0867+0.0528 \operatorname{Ln}\left(\frac{G S_{t}+G S T_{t}}{G F_{t}}\right) \\
& \left(21.0512^{* * *}\right)\left(5.8929^{* * *}\right) \\
& \overline{\boldsymbol{R}^{2}}=0.6277, \mathrm{SE}=0.0162, \mathrm{~F}=34.7260, \mathrm{DW}=0.7527
\end{aligned}
$$

Type (3), $\boldsymbol{G F}_{\boldsymbol{t}}, \boldsymbol{G} \boldsymbol{S}_{\boldsymbol{t}}$ and $\boldsymbol{G} \boldsymbol{T}_{\boldsymbol{t}}$ are indicated by the price was calculated 1980 the first industry, the second industry and the tertiary industry added value. The estimated is results showed that, compared with the value added of the First Industry, the Secondary Industry, tertiary Industry output increased with the increasing of population urbanization rate. In second, the output value of tertiary Industry and the first industrial output ratio of Population Urbanization rate elasticity coefficient is
0.0528.The results is show that blame farming industry increases value relative to the agricultural added value increased by 1 percentage points, the Population Urbanization rate rose 0.0528 percentage points. From the model, (3) type that, in the first order autocorrelation. Therefore ,we introduce a phase lag variable being explained, $\boldsymbol{U} \boldsymbol{R}_{\boldsymbol{t}-1}$ as an explanatory variable, Get the following model:

$$
\begin{aligned}
& U R_{t}=0.2239+0.0219 \operatorname{Ln}\left(\frac{G S_{t}+G T_{t}}{G F_{t}}\right)+0.0540 U R_{t-1} \\
& \left(6.2102^{* * *}\right)\left(2.1951^{* *}\right)(3.7649 * * *) \\
& \overline{R^{2}}=0.7838, \mathrm{SE}=0.0117, \mathrm{~F}=35.4476, \mathrm{DW}=1.5612
\end{aligned}
$$

The results is show that, blame farming industry increases value and added value of agricultural industry to the relative change of Urbanization elasticity coefficient is 0.0219 , at the same time, the population of the Bijie City Urbanization rate increase with year of Urbanization level has great significant relationship[13].

\section{B. Granger causality test}

Urbanization of Population and Industrial structure between the Granger causality test results as shown in TABLE2, TABLE 2 is shows that: From the Bijie City Industrial structure of Population Urbanization between the one-way causal relationship, namely, the adjustment and

\begin{tabular}{|c|c|c|c|c|}
\hline The null hypothesis & $\begin{array}{l}\text { The } \\
\text { lagging } \\
\text { number }\end{array}$ & $\begin{array}{c}\text { The } \\
\text { value of } \\
\text { F }\end{array}$ & $\begin{array}{l}\text { The } \\
\text { value } \\
\text { of } P\end{array}$ & Conclusion \\
\hline $\begin{array}{l}\text { The industrial structure of } \\
{[\mathrm{Ln}(\mathrm{GSt}+\mathrm{GTt}) / \mathrm{GFt}] \text { does }} \\
\text { not cause population town } \\
\text { changes rate ( URt) }\end{array}$ & 2 & 3.9812 & $0.0428^{* *}$ & Refuse \\
\hline $\begin{array}{l}\text { The population urbanization } \\
\text { rate ( URt ) does not cause } \\
\text { industrial structure change of } \\
{\left[\mathrm{Ln}\left(\mathrm{GS}_{\mathrm{t}}+\mathrm{GT}_{\mathrm{t}}\right) / \mathrm{GFt}\right]}\end{array}$ & 2 & 1.2495 & 0.3167 & Accept \\
\hline $\begin{array}{c}\text { The industrial structure of } \\
{\left[\mathrm{Ln}\left(\mathrm{GS}_{\mathrm{t}}+\mathrm{GT}_{\mathrm{t}}\right) / \mathrm{GF}_{\mathrm{t}}\right] \text { does not }} \\
\text { cause population town } \\
\text { changes rate }\left(\mathrm{LnUR}_{\mathrm{t}}\right)\end{array}$ & 2 & 4.2666 & $0.0357^{* *}$ & Refuse \\
\hline $\begin{array}{l}\text { Population urbanization rate } \\
\left(\mathrm{LnUR}_{\mathrm{t}}\right) \text { does not cause } \\
\text { industrial structure change of } \\
\quad\left[\mathrm{Ln}\left(\mathrm{GS}_{\mathrm{t}}+\mathrm{GT}_{\mathrm{t}}\right) / \mathrm{GF}_{\mathrm{t}}\right]\end{array}$ & 2 & 1.3665 & 0.2870 & Accept \\
\hline
\end{tabular}
upgrade of Industrial structure is to promote the Urbanization rate has increased by reason, town changes a level to rise is the upgrading of the Industrial structure of reason[14].

TABLE II. THE POPULATION URBANIZATION AND INDUSTRIAL STRUCTURE BETWEEN GRANGER CAUSALITY TEST 


\section{CONCLUSION}

\section{A. Economic growth and structural change of the Population Urbanization has one-way causal relationship}

1978 - 2014 period in Bijie's Economic growth and structural change on the Population Urbanization effect, and not as big as some scholars claimed .Economic growth and Industrial structure change can only partly explain during Bijie city Population Urbanization, but Urbanization to Economic growth and structure change of enough feedback effect is not obvious. Therefore, if only the Bijie city Population town is changed rate is low due to the backward economy, industry upgrades slow is biased. At the same time, if the other conditions remain unchanged, such as policy and system unchanged, the level of Population Urbanization process accelerating, not necessarily for Economic growth and structural change have much positive effect[15].

\section{B. Structure optimization and upgrading in favor of population urbanization level}

The Industrial structure of second, three, the proportion of output value increased with the stability of the positive role. In short, Bijie city structure upgrades for the Urbanization level has stimulative effect, but the converse is not. The study, from an empirical support to the structure change and Urbanization between the related hypothesis, further proof of the Bijie region in the Economic growth, structure to upgrade promote Urbanization process play a decisive role.

\section{Vigorously develop the high value-added of the tertiary industry}

The development of Bijie high added value of the tertiary industry. Rely on progress of science and technology, advance the depth of processing, to extend the industrial chain by developing the tertiary industry, rely on to give full play to its ability of absorbing rural surplus laborers. So as to drive to promote the urbanization level in Bijie city.

\section{REFERENCES}

[1] Huang Xiaojun, Li Cheng solid,judii .Northeast area city changes and the evolution of industrial structure interaction model [J]. economic geography, 2008(10),pp. 55-58. In Chinese.

[2] Simon. Kuznets. The modern economic growth [M]. Beijing: Science Press, 1991. In Chinese.

[3] Hollis Chenery, moire Seth. "Kun. Development pattern of 19501970[M]. Beijing: China financial and Economic Publishing House, 1989.

[4] Li Chenggu, et al. City industrial structure upgrading of response of city [J]. city planning review, 2004(7),PP. 31-36. In Chinese.

[5] Liu Hongkun. Our country city changes the relationship between economic development and deviation analysis [J]. Journal of Chongqing Jianzhu University, 2003(5),pp.118-122. In Chinese.

[6] Ann Chen Ming. Husen, industrialized, city changes process and our country city is changed advance path selection of [J]. Nankai economic studies, 2005(8),pp: 48-54.

[7] Monday Star City Geography [M]. Beijing: the Commercial Press, 1997. In Chinese.

[8] Chen,Almln,Edward coulson.2001.DetermInants of Urban Population Growth:Evidence from Chinese Cities,paper presented at International Conference on Urbanization in China :Challenges and Strategies of Growth and Development. In Chinese.

[9] Xia Yongxiang, Yu its rigid. World city to change a course of general ship law and practice in China City store [A].Empirical Analysis and Countermeasures about [M]. Xiamen: Xiamen University press, 2013.

[10] Zhang Honglin China city and economic development [A].China City: Empirical Analysis and Countermeasures Research [M]. Xiamen: Xiamen University press, 2015(6),PP.18-28.

[11] Lin Lu, Yin Zhang.Difficulties and Strategies in the Process of Population Urbanization: A Case Study in Chongqing of China[J]. Tingting Luo.Open Journal of Social Sciences, 2014(2), pp.90-95.

[12] Wang, Zhangming, Wang, Chengzhang, Zhang, Qian.Population Ageing, Urbanization and Housing Demand[J].Journal of Service Science and Management, 2015(4),pp.516-525.

[13] Yue-Jun Zhang, Zhao Liu, Huan Zhang, Tai-De Tan .The impact of economic growth, industrial structure and urbanization on carbon emission intensity in China[J].Natural Hazards, 2014 (2), pp.579-595.

[14] Bai Xuemei, Chen Jing, Shi Peijun.Landscape urbanization and economic growth in China: positive feedbacks and sustainability dilemmas.[J].Environmental Science \& Technology, 2011(1), pp.132139.

[15] Pingjun Sun, Wei Song, Chunliang Xiu, Zhenming Liang.Noncoordination in China's urbanization: Assessment and affecting factors[J].Chinese Geographical Science, 2013(6), pp.729-739.

[16] Blane D. Lewis .Urbanization and Economic Growth in Indonesia: Good News, Bad News and (Possible) Local Government Mitigation [J].Regional Studies, 2014(1), pp.192-207. 